\title{
Effect of Roughage Source and Roughage to Concentrate Ratio on Animal Performance and Rumen Development in Veal Calves ${ }^{1}$
}

\author{
B. J. Suárez, ${ }^{\star}$ C. G. Van Reenen, $†$ N. Stockhofe, $†$ J. Dijkstra, ${ }^{*}$ and W. J. J. Gerrits ${ }^{\star 2}$ \\ *Animal Nutrition Group, Wageningen UR, P.O. Box 338, 6700 AH Wageningen, the Netherlands \\ †Animal Sciences Group of Wageningen UR, Division of Animal Production, P.O. Box 65, 8200 AB Lelystad, the Netherlands
}

\begin{abstract}
Sixty-four male Holstein-Friesian $\times$ Dutch Friesian veal calves $(46 \pm 3.0 \mathrm{~kg})$ were used to evaluate the effect of the inclusion of different levels and sources of dietary roughage on animal performance and rumen development. Treatments consisted of 1) $\mathrm{C} 100=$ concentrate only; 2) C70-S30 = concentrate (70\%) with straw (30\%), 3) C70-G30 = concentrate $(70 \%)$ with dried grass $(30 \%)$, 4) $\mathrm{C} 70-\mathrm{G} 15-\mathrm{S} 15=$ concentrate $(70 \%)$ with dried grass $(15 \%)$ and straw $(15 \%)$, 5) $\mathrm{C} 70-\mathrm{CS} 30=$ concentrate (70\%) with corn silage (30\%), 6) C40-CS60 = concentrate $(40 \%)$ with corn silage $(60 \%), 7) \mathrm{C} 70-\mathrm{CS} 30-\mathrm{AL}=$ concentrate $(70 \%)$ with corn silage (30\%) ad libitum, 8) C70G15-S15-AL = concentrate $(70 \%)$ with dried grass $(15 \%)$ and straw (15\%) ad libitum. All dietary treatments were provided in addition to a commercial milk replacer. Concentrate was provided as pellets and roughage was chopped. The dietary treatments 1 to 6 were supplied restrictedly to a maximum of $750 \mathrm{~g}$ of dry matter (DM) per day, whereas treatments 7 and 8 were offered ad libitum in combination with a reduced amount of milk replacer. Calves were euthanized after $10 \mathrm{wk}$. Straw supplementation (C70-S30 vs. C70-G30 and C70-CS30) reduced DM intake, and ad libitum supply of concentrate and roughage increased DM intake. Roughage addition did not affect growth performance. Rumen fermentation was characterized by low $\mathrm{pH}$ and high total volatile fatty acids and reducing sugar concentrations. Calves fed ad libitum showed lower ruminal lactate concentrations than calves fed restrictedly. Ammonia concentrations were highest in calves fed C-100 and lowest in calves fed ad libitum. The recovery of CoEDTA (added to milk replacer) varied between 20.5 and 34.9\%, indicating that significant amounts of milk entered the rumen. Roughage addition decreased the incidence of plaque formation (rumen mucosa containing focal or

\footnotetext{
Received August 10, 2006.

Accepted December 12, 2006.

${ }^{1}$ This study was partially supported by the Dutch Product Board

${ }^{2}$ Corresponding author: Walter.Gerrits@wur.nl
} of Feed.
\end{abstract}

multifocal patches with coalescing and adhering papillae covered by a sticky mass of feed, hair and cell debris) and the incidence of calves with poorly developed rumen mucosa. However, morphometric parameters of the rumen wall were hardly influenced by the type and level of roughage. Ruminal polysaccharide-degrading enzyme activities reflected the adaptation of the microorganisms to the dietary concentrate and roughage source. Results indicated that in veal calves, the addition of roughage to concentrate diets did not affect growth performance and positively influenced the macroscopic appearance of the rumen wall.

Key words: veal calf, concentrate composition, roughage composition, rumen fermentation

\section{INTRODUCTION}

Ingestion of solid feed is necessary to stimulate rumen development in the young calf. Concentrate diets are generally provided because DMI and VFA production are higher than with diets based only on roughage. Volatile fatty acids are required for rapid development of the rumen papillae (Flatt et al., 1958). On the other hand, concentrate diets may cause a rapid accumulation of the fermentation end products accompanied by a decrease in $\mathrm{pH}$ (Beharka et al., 1998), a decrease in rumen motility (Nocek, 1997; Owens et al., 1998), overgrowth and keratinization of the rumen papillae (Nocek and Kesler, 1980), and consequently, a decrease in VFA absorption (Hinders and Owen, 1965). In previous research with concentrate-fed veal calves a particular rumen environment was observed, characterized by a low $\mathrm{pH}(<5.2)$, relatively low VFA concentrations (100 to $120 \mathrm{mmol} / \mathrm{L}$ ), high concentrations of reducing sugars (45 to $124 \mathrm{~g} / \mathrm{kg}$ of DM), and high activity of microbial polysaccharide-degrading enzymes (PDE; Suárez et al., 2006a). In addition, and depending on concentrate composition, poorly shaped papillae and a high incidence of foci with feed and cell debris sticking to the rumen wall (referred to as plaque formation in this paper) were observed (Suárez et al., 2006b).

In veal calves, typically fed with milk replacer and supplemented with relatively small quantities of con- 
centrates, information concerning the effects of roughage intake on performance and rumen development is scarce (Blokhuis et al., 2000; Cozzi et al., 2002). Feeding roughage without concentrates to young calves generally does not promote rapid papillae development, probably due to insufficient VFA production rates (Nocek and Kesler, 1980). Roughage consumption, however, stimulates muscle development of the rumen wall (Tamate et al., 1962) and promotes rumination (Hodgson, 1971). Furthermore, the physical characteristics present in the roughages, such as coarseness, bulkiness, and abrasiveness, have been reported as necessary to maintain the integrity and healthiness of the rumen wall (Haskins et al., 1969). Therefore, it was hypothesized that adding roughage to a concentrate diet would reduce the incidence of poorly developed mucosa and plaque formation observed in concentrate-fed veal calves (Suárez et al., 2006a,b) and stimulate the development of the rumen wall, without negative effects on performance.

The objective of the present experiment was to determine the effect of various roughage sources, concentrate to roughage ratios, and intake levels of concentrate and roughage fed in addition to a milk replacer diet on rumen development and growth performance of veal calves.

\section{MATERIALS AND METHODS}

The present experiment was conducted at the experimental farm of Wageningen University and Research Center in Lelystad, the Netherlands. Experimental procedures complied with the Dutch law on experimental animals.

\section{Calves, Diets, Transport, and Slaughter Procedure}

Sixty-four Holstein-Friesian $\times$ Dutch Friesian male calves of approximately $10 \mathrm{~d}$ of age $(46 \pm 3.0 \mathrm{~kg})$ were allotted to 1 of 8 blocks, and within blocks were randomly assigned to 1 of 8 dietary treatments. Calves were housed in individual $0.9-\mathrm{m}^{2}$, mesh-bottomed pens without bedding material. Ambient temperature was maintained at least at $15^{\circ} \mathrm{C}$.

Dietary treatments (Table 1) consisted of a $100 \%$ concentrate control treatment and 7 treatments in which a variety of roughage sources were supplied in various quantities in addition to a commercial milk replacer $(970.9 \mathrm{~g} / \mathrm{kg}$ of DM; $36.8 \mathrm{~g} / \mathrm{kg}$ of $\mathrm{N} ; 181 \mathrm{~g} / \mathrm{kg}$ of crude fat; $73.5 \mathrm{~g} / \mathrm{kg}$ of ash). Milk replacer and dietary treatments were offered to the calves twice daily (0600 and 1600 h). The roughage sources used were either corn silage, barley straw, or dried grass. Treatments were 1) $\mathbf{C 1 0 0}=$ concentrate only, 2) $\mathbf{C 7 0 - S 3 0}=$ concentrate $(70 \%)$ with straw (30\%), 3) C70-G30 = concentrate (70\%) with dried grass (30\%), 4) C70-G15-S15 = concentrate $(70 \%)$ with dried grass (15\%) and straw (15\%), 5) C70-CS30 = concentrate $(70 \%)$ with corn silage $(30 \%), 6)$ C40-CS60 = concentrate (40\%) with corn silage (60\%), 7) C70-CS30$\mathbf{A L}=$ concentrate $(70 \%)$ with corn silage $(30 \%)$ fed ad libitum, 8) C70-G15-S15-AL = concentrate $(70 \%)$ with dried grass (15\%) and straw (15\%) fed ad libitum. Ingredient and nutrient composition of the concentrate as well as the nutrient composition of roughages is presented in Table 2. Total nutrient composition of the various treatments can be calculated from the diet composition (proportion of roughage and concentrate in the diet; Table 1) and the nutrient composition of roughages and concentrates (Table 2). The concentrate was provided as pellets and the roughages were chopped. Except for the ad libitum treatments, the supplied DMI from concentrates and roughage was maximized at 750 $\mathrm{g} / \mathrm{d}$, and for these restricted-fed diets, the daily supply of milk replacer was gradually increased and amounted to $360,480,530,570,620,700,810,980,1,170$, and $1,360 \mathrm{~g} / \mathrm{d}$ in wk 1 to 10 , respectively. For the ad libitum treatments, the supply of milk replacer was identical to the restricted-fed treatments up to wk 6 , but remained constant at $700 \mathrm{~g} / \mathrm{d}$ thereafter. Concentrates and roughages portions were weighed and mixed separately $(50 \%$ of the expected daily intake per meal), and supplied in a different bucket immediately after the calves had finished the milk replacer. Buckets were weighed and emptied before the next milk replacer meal, and pooled samples of concentrates, roughage sources, and orts were obtained for chemical analysis. To avoid selective intake of concentrates or roughages, the daily supply was based on minimization of orts. Therefore, the expected DMI of a calf was calculated weekly based on the realized DMI of that calf in the previous week and a projected weekly increase.

Calves were euthanized after 10 wk by an intravenous administration of T61 (Embutramide, Intervet International, Unterschleissheim, Germany). To quantify ruminal drinking, $3.0 \mathrm{~g}$ of CoEDTA (Uden et al., 1980) was dissolved into the final milk replacer meal. Calves were assigned to 1 of 4 consecutive slaughtering days (balanced across dietary treatments), and to 1 of 4 fixed intervals of 1.5, 2.5, 3.5, and $4.5 \mathrm{~h}$ between the last milk feeding and time of slaughter. Before slaughter and after calves finished the milk replacer, calves were allowed to consume the concentrate and roughage portions for $30 \mathrm{~min}$. Then, calves were transported from the experimental farm to the pathology lab (5 $\mathrm{min})$ and euthanized. To avoid reflux of milk replacer containing CoEDTA from the abomasum into the forestomachs, the calves were lifted by the forelegs, and the stomach was tied caudal of the pylorus and caudal of the esopha- 
Table 1. Milk replacer scheme, concentrate and roughage source, amount of DM supplied, and diet designations

\begin{tabular}{|c|c|c|c|c|c|c|c|}
\hline \multirow[b]{2}{*}{ Dietary treatment } & \multirow{2}{*}{$\begin{array}{l}\text { Milk } \\
\text { replacer } \\
\text { scheme }^{1}\end{array}$} & \multicolumn{4}{|c|}{$\begin{array}{l}\text { Concentrate or roughage source, } \\
\text { proportion }(\%) \text { of DM supply }\end{array}$} & \multirow{2}{*}{$\begin{array}{l}\text { Maximum } \\
\text { supplied } \\
\text { (g of } \mathrm{DM} / \mathrm{d} \text { ) }\end{array}$} & \multirow{2}{*}{$\begin{array}{c}\text { Diet } \\
\text { designation }\end{array}$} \\
\hline & & Concentrate $^{2}$ & Straw $^{3}$ & Grass $^{4}$ & Corn silage ${ }^{5}$ & & \\
\hline Concentrate + corn silage & 1 & 40 & - & - & 60 & 750 & C40-CS60 \\
\hline Concentrate + straw & 1 & 70 & 30 & - & - & 750 & C70-S30 \\
\hline Concentrate + grass & 1 & 70 & - & 30 & - & 750 & C70-G30 \\
\hline Concentrate + corn silage & 1 & 70 & - & - & 30 & 750 & C70-CS30 \\
\hline Concentrate + grass + straw & 2 & 70 & 15 & 15 & - & Ad libitum & C70-G15-S15-AL \\
\hline
\end{tabular}

${ }^{1}$ Milk replacer scheme 1: daily supply of milk replacer was gradually increased and amounted to $360,480,530,570,620,700,810,980$, 1,170 , and $1,360 \mathrm{~g} / \mathrm{d}$ in wk 1 to 10 , respectively; scheme 2 : daily supply of milk replacer amounted to $360,480,530,570,620$, and 700 in wk 1 to 6 , and $700 \mathrm{~g} / \mathrm{d}$ for the remainder of the study.

${ }^{2}$ Concentrate composition in Table 2.

${ }^{3}$ Chopped barley straw.

${ }^{4}$ Chopped dried grass.

${ }^{5}$ Corn silage: maximal $120 \mathrm{mg} / \mathrm{kg}$ of iron on DM basis.

gus and removed. The rumen weight was recorded with and without its contents. Rumen DM pool (kg) can be calculated from fresh rumen content weight and its DM content. Rumen Co pool size (kg) was calculated from rumen DM pool $(\mathrm{kg})$ and Co concentration $(\mathrm{mg} / \mathrm{kg}$ of DM); Co recovery (\%) was expressed as a percentage of Co intake (initial pulse dose). The fractional rumen liquid passage rate was calculated as the slope of the regression of the natural logarithm of the Co pool size against the time interval between milk feeding and slaughter.

The rumen was dissected along the dorsal line, emptied, and rinsed with cold water. The examination and assessment of the rumen mucosa and sites of sampling of the rumen wall for further morphometric analysis were carried out as described by Suárez et al. (2006b). Briefly, the mucosal surface was visually examined and qualitatively assessed according to the presence and

Table 2. Ingredient and analyzed nutrient composition of the concentrates and roughages

\begin{tabular}{|c|c|c|c|c|c|}
\hline Ingredient & IFN $^{1}$ & Concentrate & Corn silage & Straw & Grass \\
\hline Beet pulp, ground, \% & $4-00-672$ & 30.3 & - & - & - \\
\hline Soybean hulls, $\%$ & $1-04-560$ & 15.5 & - & - & - \\
\hline Corn grits, $\%$ & $4-03-011$ & 15.5 & - & - & - \\
\hline Corn, broken, \% & $4-20-689$ & 15.5 & - & - & - \\
\hline Barley, crushed, \% & $4-00-549$ & 15.5 & - & - & - \\
\hline Soybean oil, \% & $\mathrm{NA}^{2}$ & 0.5 & - & - & - \\
\hline Soluble wheat protein, $\%$ & NA & 4.0 & - & - & - \\
\hline Urea, \% & NA & 1.2 & - & - & - \\
\hline Vinasse, $\%$ & NA & 2.0 & - & - & - \\
\hline \multicolumn{6}{|l|}{ Analyzed nutrient composition } \\
\hline $\mathrm{DM}, \mathrm{g} / \mathrm{kg}$ of product & & 878 & 360 & 899 & 881 \\
\hline $\mathrm{CP}, \mathrm{g} / \mathrm{kg}$ of DM & & 193 & 68 & $\mathrm{BD}$ & 227 \\
\hline Crude fat, $\mathrm{g} / \mathrm{kg}$ of $\mathrm{DM}$ & & 41 & - & - & - \\
\hline Crude ash, g/kg of DM & & 48 & 46 & 101 & 122 \\
\hline Starch, g/kg of DM & & 250 & 375 & $\mathrm{BD}^{3}$ & 6 \\
\hline Sugars, g of glucose/kg of DM & & 47 & 7 & $\mathrm{BD}$ & 84 \\
\hline $\mathrm{NDF}, \mathrm{g} / \mathrm{kg}$ of $\mathrm{DM}$ & & 292 & 343 & 805 & 433 \\
\hline $\mathrm{ADF}, \mathrm{g} / \mathrm{kg}$ of $\mathrm{DM}$ & & 158 & 193 & 525 & 233 \\
\hline $\mathrm{ADL},{ }^{4} \mathrm{~g} / \mathrm{kg}$ of $\mathrm{DM}$ & & 8 & 13 & 63 & 22 \\
\hline $\mathrm{Ca}, \mathrm{g} / \mathrm{kg}$ of $\mathrm{DM}$ & & 4.7 & 1.6 & 3.2 & 7.3 \\
\hline $\mathrm{P}, \mathrm{g} / \mathrm{kg}$ of $\mathrm{DM}$ & & 2.3 & 2.0 & 0.3 & 3.9 \\
\hline
\end{tabular}

${ }^{1}$ IFN = International Feed Number (obtained from NRC, 1989).

${ }^{2} \mathrm{NA}=$ not available.

${ }^{3} \mathrm{BD}=$ below detection levels $(=7.5 \mathrm{mg}$ of $\mathrm{Cu} / \mathrm{kg}$ of DM; $0.075 \mathrm{~g}$ of $\mathrm{Na} / \mathrm{kg}$ of DM; $6 \mathrm{~g}$ of sugars $/ \mathrm{kg}$ of DM; $3 \mathrm{~g}$ of starch/kg; $19 \mathrm{~g}$ of $\mathrm{CP} / \mathrm{kg}$ of DM; $3 \mathrm{~g}$ of N/kg $\times 6.25)$.

${ }^{4} \mathrm{ADL}=$ acid detergent lignin. 
density of rumen papillae as follows: $1=$ poor (small number of papillae or short papillae) and $2=\operatorname{good}($ numerous papillae or long papillae). The incidence of plaque (rumen mucosa containing focal or multifocal patches with coalescing and adhering papillae covered by a sticky mass of feed, hair and cell debris) was visually assessed. The morphometric analyses were conducted in 4 slides (embedded in paraffin, stained with hematoxylin-eosin) cut from a $2 \times 2 \mathrm{~cm}$ section of rumen wall tissue taken either from a dorsal or a ventral location in the rumen. The measurements comprised a) the ratio of mucosa length to serosa length (RMSL) as a measure of absorptive area and determined as the length of the mucosal surface within a slide divided by the length of the corresponding serosa (the latter being about $2 \mathrm{~cm}$ ); b) mucosa thickness (MCT), measured at 3 randomly chosen sites within each slide; and c) muscle thickness (MST), measured at the same sites as for MCT. The measurement of MCT was chosen to avoid bias of the observer by defining suitable, measurable papillae in a slide, as irregular shapes of papillae frequently occurred. Morphometrical analyses were performed at a magnification of 2.5× (Olympus microscope; Olympus Corporation, Tokyo, Japan) by using the image analysis software Image Pro Plus (Media Cybernetics, Silver Spring, MD).

By using a metal sieve $(1.5 \mathrm{~mm})$, the solid and liquid phases of the rumen contents were separated and weighed. The separation of both phases was done by gently squeezing the rumen contents until no more leakage of liquid was observed. A representative sample of rumen contents was reconstituted from the solid and liquid phases.

Rumen $\mathrm{pH}$ was measured in the rumen liquid. Rumen liquid was centrifuged $(1,000 \times g, 10 \mathrm{~min})$, sampled, acidified with ortho-phosphoric acid, and stored at $-20^{\circ} \mathrm{C}$ until analysis.

\section{Analytical Procedures}

Dry matter was determined by drying at $103^{\circ} \mathrm{C}$ and ash by combustion at $550^{\circ} \mathrm{C}$ according to standards ISO 6496 (ISO, 1983) and ISO 5948 (ISO, 1978), respectively. Kjeldahl $\mathrm{N}$ and fat content were determined based on ISO 5983 (ISO, 1998) and 6492 (ISO, 1999), respectively, and total starch was analyzed according to Brunt (1993). Reducing sugars (RS) were extracted from the dried rumen samples using $40 \%$ ethanol and determined as described by Suárez et al. (2006a). Neutral detergent fiber, ADF, and acid detergent lignin were analyzed according to a method adapted from Van Soest et al. (1991). Briefly, after the neutral detergent treatment incubation, an enzyme cocktail containing termamyl (Novo Nordisk, Copenhagen, DK), amylase
(Sigma 6814, Sigma-Aldrich, St. Louis, MO) and protease (Novo Nordisk) in phosphate buffer ( $\mathrm{pH} 7.0$ ) was added to remove starch and proteins from the residue. For ADF determination, the samples were first treated as in the NDF methodology, and then, the residues were incubated with acid detergent as described by Van Soest and McQueen (1973). The acid detergent lignin analysis was based on the treatment of the sample with acid detergent followed by incubation with $72 \%$ sulfuric acid.

The VFA and lactic acid concentrations were analyzed using HPLC with a Merck polyspher OA 51272 column as stationary phase (Merck \& Co., Inc., Whitehouse Station, NJ) and $0.0025 M$ sulfuric acid as mobile phase (elution fluid) and a refractive index detector. Calibration and quantification was done by using an external standard solution. Ammonia concentrations were estimated according to the Berthelot method, modified by Schneider (1976).

For the CoEDTA determination, samples of whole rumen contents were freeze-dried, ground, and subsequently incinerated at 250 and $550^{\circ} \mathrm{C}$. The remaining ash was destructed with concentrated nitric acid during $2 \mathrm{~h}$ at $100^{\circ} \mathrm{C}$. The supernatant was diluted with a solution containing lithium-chloride and yttrium (as internal standard). The content of Co was measured by inductively coupled plasma optical emission spectrometry at $228.616 \mathrm{~nm}$.

Isolation of rumen enzymes and subsequent measurement of their activities were carried out as described by Suárez et al. (2006a). The substrates incubated with the enzyme cocktails were suspensions ( $2 \%$ wt/vol) of sugar beet pulp, soybean hulls, native cornstarch, and straw. Incubates, substrate blanks, and enzyme extract blanks were analyzed for RS end-groups according to Somogyi (1952). After correcting by substrate and enzyme extracts blanks, the enzyme activity was expressed as millimoles of RS released per minute per gram of DM in the rumen. If desired, enzyme activity can be expressed on a whole rumen basis by multiplying the enzyme activity per unit of DM and the total rumen DM pool size.

\section{Statistical Analysis}

Data for rumen fermentation parameters, empty rumen weight, and rumen wall parameters were analyzed as a complete randomized block design, with dietary treatments as main factor. Continuous data were subjected to ANOVA according to model 1 :

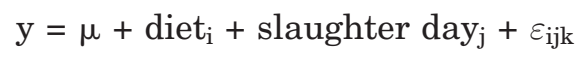

where $\mathrm{y}$ is the dependent variable; $\mu$ is the average experimental value; diet $_{\mathrm{i}}$ is the effect of dietary treat- 


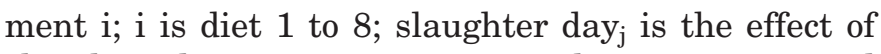
slaughter day $\mathrm{j} ; \mathrm{j}$ is $1, \ldots, 4 ; \varepsilon_{\mathrm{ijk}}$ is the error term; and $\mathrm{k}=1, \ldots, 64$ (i.e., calf).

The same model, but excluding the effect of slaughter day, was used to analyze data of DMI and ADG.

The parameters in which the postfeeding slaughter time was expected to have an effect (rumen $\mathrm{pH}$, ruminal VFA concentrations, and CoEDTA recovery) were analyzed using the following model:

$$
\begin{gathered}
\mathrm{y}=\mu+\text { diet }_{\mathrm{i}}+\text { slaughter }_{\text {day }_{\mathrm{j}}}+\text { interval }_{\mathrm{k}} \\
+(\text { diet } \times \text { interval })_{\mathrm{ik}}+\varepsilon_{\mathrm{ijk}}
\end{gathered}
$$

where $\mathrm{y}$ is the dependent variable; $\mu$ is the average experimental value; diet $_{i}$ is the effect of dietary treat-

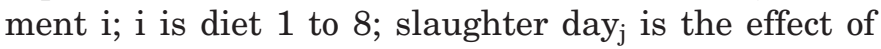
slaughter day $\mathrm{j} ; \mathrm{j}=1, \ldots, 4$; interval $\mathrm{k}_{\mathrm{k}}$ is the effect of interval from feeding to slaughter ; $\mathrm{k}$ is 1.5, 2.5, 3.5, 4.5 $\mathrm{h}$; (diet $\times$ interval $_{\mathrm{ik}}$ is the effect of interaction between dietary treatment and interval from feeding to slaughter; and $\varepsilon_{\mathrm{ijkl}}$ is the error term; and $\mathrm{l}=1, \ldots, 64$ (i.e., calf).

The $F$-test was used to evaluate the effect of dietary treatment. For the analysis of fractions (percentages), a logistic regression model was used with the same main effects as described earlier. Inferences for fractions were based on likelihood ratio tests. Dispersion parameters were estimated from Pearson's generalized test (McCullagh and Nelder, 1989). Posthoc pairwise comparisons between diets were carried out using the Fisher LSD method (for fractions on a logistic scale), employing the pooled error variance from the ANOVA. In addition, predetermined contrasts between specific (combinations of) feed rations were examined, including A) roughage supplementation: $\mathrm{C} 100$ vs. all roughage containing diets, except the 2 ad libitum diets; B) the effect of source of roughage supplementation: C70-S30 vs. C70-G30 vs. C70-CS30; C) the effect of supplementing a single or a combined source of roughage: C70-G15-S15 vs. (C70-S30 and C70-G30); D) the effect of different levels of roughage supplementation: C70CS30 vs. C40-CS60; and E) the effect of restricted vs. ad libitum roughage supplementation: (C70-G15-S15 and C70-CS30) vs. (C70-G15-S15-AL and C70-CS30AL). Each contrast was tested for significance with a $t$-test, again using the pooled error variance from the ANOVA. Measures of rumen fermentation $(\mathrm{pH}$, total VFA concentrations and their molar proportions, lactate, and ammonia), empty rumen weight, and morphometric variables of the rumen wall were also subjected to analyses of covariance, introducing DMI as a covariable in the appropriate ANOVA model (see above). For measures of rumen fermentation, the average DMI during the last week prior to slaughter was used as a covari- able and expressed as the deviation from the overall mean. For the empty rumen weight and morphometric variables of the rumen wall, the average DMI during the entire experimental period was used as a covariable and likewise expressed as the deviation from the overall mean. In this manner, least squares means of dependent variables following analyses of covariance were appropriately corrected for differences in DMI. Binary variables were analyzed parameter-free using the Fisher exact test. Significance was determined at $P<$ 0.05 unless indicated otherwise. All calculations were performed with Genstat (Genstat Committee, 2000).

The rumen enzyme activities were analyzed as a complete randomized block design with dietary treatments and substrates as main factors by using the GLM procedure of SAS (SAS Institute, 2002) according to model 3:

$$
\begin{aligned}
& y=\mu+\text { diet }_{i}+\text { substrate }_{j} \\
& +\left(\operatorname{diet} \times \text { substrate }_{i j}+\varepsilon_{i j k}\right.
\end{aligned}
$$

where $\mathrm{y}$ is the dependent variable; $\mu$ is the average experimental value; diet $_{\mathrm{i}}$ is the effect of dietary treatment $i$; i is diet 1 to 8 ; substrate $e_{j}$ is the effect of substrate $\mathrm{j}, \mathrm{j}$ is soybean hulls, native cornstarch, sugar beet pulp, or straw; and $\varepsilon_{\mathrm{ijk}}$ is the error term.

Main effects and the interaction between diets and substrate were evaluated. Moreover, predetermined contrasts between diets (mentioned above) were performed by substrate.

\section{RESULTS}

\section{Feed Intake and BW Gain}

Throughout the experiment, no signs of illness were observed. The least squares means for milk replacer intake, nonmilk replacer DMI, as well as for final BW, ADG, and feed conversion are presented in Table 3. If desired, total nutrient intakes (from milk plus solid feeds) can be calculated from the knowledge of the milk replacer composition, solid feeds composition, and their respective intakes.

The average DMI from concentrate and roughage of the restricted-fed calves ranged from 0.43 to $0.59 \mathrm{~kg} / \mathrm{d}$ and for the ad libitum-fed groups from 0.78 to $0.81 \mathrm{~kg} /$ d. Calves fed the C70-G30 and C70-CS30 diets had a higher average DMI (0.59 and $0.55 \mathrm{~kg} / \mathrm{d}$, respectively) compared with calves fed the C70-S30 diet $(0.43 \mathrm{~kg} / \mathrm{d}$; contrast $\mathrm{B} ; P<0.05)$. In wk 5 and 6 this contrast was also significant, but not in wk 1 and wk 10 . In addition, calves fed ad libitum showed a higher overall DMI and higher DMI in wk 6 and 10 than restricted-fed calves (contrast E; $P<0.001$ ). 
ROUGHAGE SOURCE AND ROUGHAGE TO CONCENTRATE RATIO

Table 3. Effect of dietary treatments on milk replacer intake, DMI, final BW, ADG, and feed conversion ratio

\begin{tabular}{|c|c|c|c|c|c|c|c|c|c|c|c|c|c|c|}
\hline \multirow[b]{3}{*}{ Variable } & \multicolumn{8}{|c|}{ Dietary treatment ${ }^{1}$} & \multirow[b]{3}{*}{ SEM } & \multirow{2}{*}{\multicolumn{5}{|c|}{ Contrast $^{2}$}} \\
\hline & & $\mathrm{C} 40-$ & C70- & C70- & C70- & C70- & C70- & C70-G15- & & & & & & \\
\hline & C100 & CS60 & $\mathrm{S} 30$ & G30 & CS30 & G15-S15 & CS30-AL & S15-AL & & A & B & $\mathrm{C}$ & $\mathrm{D}$ & $\mathrm{E}$ \\
\hline $\mathrm{kg} / \mathrm{d}$ (wk 1 to 10$)$ & 0.50 & 0.49 & $0.43^{\mathrm{b}}$ & $0.59^{\mathrm{a}}$ & $0.55^{\mathrm{a}}$ & 0.54 & 0.81 & 0.78 & 0.043 & NS & $*$ & NS & NS & **** \\
\hline wk 1 & 0.12 & 0.07 & 0.07 & 0.09 & 0.09 & 0.06 & 0.12 & 0.09 & 0.025 & NS & NS & NS & NS & NS \\
\hline wk 10 & 0.50 & 0.60 & 0.53 & 0.72 & 0.67 & 0.69 & 1.26 & 1.47 & 0.069 & NS & NS & NS & NS & $* * *$ \\
\hline Final BW, kg & 99.5 & 97.8 & 95.6 & 102.3 & 101.4 & 99.8 & 99.0 & 96.1 & 2.2 & NS & NS & NS & NS & NS \\
\hline ADG, g/d & 754 & 726 & $688^{\mathrm{b}}$ & $779^{\mathrm{a}}$ & $774^{\mathrm{a}}$ & 753 & 742 & 696 & 29 & NS & $*$ & NS & NS & NS \\
\hline $\begin{array}{l}\text { Feed conversion, total } \\
\mathrm{kg} \text { of } \mathrm{DMI} / \mathrm{kg} \text { of growth }\end{array}$ & 1.64 & 1.70 & 1.69 & 1.69 & 1.66 & 1.69 & 1.88 & 1.96 & 0.041 & NS & NS & NS & NS & $* * *$ \\
\hline
\end{tabular}

${ }^{\text {a,b }}$ Means in the same row, within columns C70-S30, C70-G30, and C70-CS30 with different superscript differ significantly $(P<0.05)$.

${ }^{1}$ Treatments: $\mathrm{C} 100=$ concentrate only; C40-CS60 = concentrate $(40 \%)$ with corn silage $(60 \%)$; C70-S30 = concentrate $(70 \%)$ with straw (30\%); C70-G30 = concentrate $(70 \%)$ with dried grass (30\%); C70-CS30 = concentrate (70\%) with corn silage (30\%); C70-G15-S15 = concentrate (70\%) with dried grass (15\%) and straw (15\%); C70-CS30-AL = concentrate (70\%) with corn silage (30\%) fed ad libitum; and C70-G15-S15$\mathrm{AL}=$ concentrate $(70 \%)$ with dried grass $(15 \%)$ and straw $(15 \%)$ fed ad libitum.

${ }^{2}$ Contrasts: $\mathrm{A}=\mathrm{C} 100$ vs. (all diets with additional roughage except the 2 ad libitum diets); B = C70-S30 vs. C70-G30 vs. C70-CS30 (mutually); $\mathrm{C}=\mathrm{C} 70-\mathrm{G} 15-\mathrm{S} 15$ vs. (C70-S30 and C70-G30); D = C70-CS30 vs. C40-CS60; $\mathrm{E}=(\mathrm{C} 70-\mathrm{G} 15-\mathrm{S} 15$ and C70-CS30) vs. (ad libitum diets).

${ }^{3} \mathrm{DMI}$ from concentrate and roughage, excluding DMI from milk.

${ }^{4}$ Total DMI (including milk replacer)/BW gain.

$* P \leq 0.05 ; * * * P<0.001$.

The weight at slaughter was not affected by the diets. Average daily gain ranged from 688 to $779 \mathrm{~g} / \mathrm{d}$. Calves fed the C70-G30 and C70-CS30 diets had increased ADG (779 and $774 \mathrm{~g} / \mathrm{d}$, respectively) compared with those on the C70-S30 treatment $(668 \mathrm{~g} / \mathrm{d}$; contrast B; $P<0.05)$. Feed conversion was not affected by dietary treatments among restricted-fed calves $(P>0.05)$, but it was increased in the calves of the ad libitum-fed groups $(P<0.001$; contrast $\mathrm{E})$.

\section{Rumen Fermentation Parameters}

The effects of dietary treatments on rumen weight and fermentation parameters are shown in Table 4 . The $\mathrm{pH}$ in rumen liquid varied between 5.1 and 5.3 and was higher for calves fed the C70-G15-S15 diet than for calves on the C70-S30 and C70-G30 treatments (contrast $\mathrm{C} ; P<0.05$ ).

The total VFA concentration in rumen fluid ranged from 108 to $150 \mathrm{mmol} / \mathrm{L}$ and was slightly lower in calves fed the C40-CS60 than in those fed the C70-CS30 diet (contrast D; $P<0.10$ ). Substituting part of the concentrate with roughage increased acetate and decreased propionate molar proportions (contrast A; $P<0.001$ ). The molar proportion of acetate increased and that of butyrate decreased when straw was the single source of roughage (contrast B; $P<0.001$ and $P<0.05$, respectively). Furthermore, the molar proportion of propionate decreased from 27.3 to $21.6 \%$ by increasing the corn silage to concentrate ratio (contrast $\mathrm{D} ; P<0.01$ ). Finally, calves fed a roughage combination of dried grass and straw (C70-G15-S15) tended to have a lower molar proportion of propionate in comparison with calves fed either only dried grass or only straw as source of roughage (contrast $\mathrm{C} ; P<0.1$ ).

The molar proportion of isobutyrate in the rumen liquid was lower in C70-G30 fed calves than in those fed either the C70-S30 or C70-CS30 diets (contrast B; $P<0.05$ ). In addition, lower molar proportions of isobutyrate and of methyl-butyrate were observed in ad libitum-fed calves (contrast E; $P<0.05$ and $P<0.01$, respectively). The molar proportion of methyl-butyrate was higher in calves fed a roughage combination of dried grass and straw (C70-G15-S15; contrast C; $P<0.001$ ). A tendency to a higher molar proportion of methylbutyrate was present in calves fed diets with a higher corn silage to concentrate ratio (contrast $\mathrm{D} ; P<0.1$ ). Finally, lower molar proportions of valerate were observed in calves fed straw compared with calves fed either dried grass or corn silage as additional source of roughage (contrast $\mathrm{B} ; P<0.001$ ).

Lactate concentrations varied between 2.0 and 11.8 $\mathrm{mmol} / \mathrm{L}$ and were lower in calves fed ad libitum (contrast $\mathrm{E} ; P<0.05)$. Furthermore, rumen lactate concentrations were slightly lower in calves fed C70-CS30 than in calves fed C70-G30 (4.6 vs. $10.9 \mathrm{mmol} / \mathrm{L}$; contrast B; $P<0.1$ ). 
Table 4. Effect of dietary treatments on rumen fermentation characteristics, weight of rumen contents, and Co recovery

\begin{tabular}{|c|c|c|c|c|c|c|c|c|c|c|c|c|c|c|}
\hline \multirow[b]{3}{*}{ Variable } & \multicolumn{8}{|c|}{ Dietary treatment ${ }^{1}$} & \multirow[b]{3}{*}{ SEM } & \multirow{2}{*}{\multicolumn{5}{|c|}{ Contrast $^{2}$}} \\
\hline & & $\mathrm{C} 40-$ & C70- & C70- & C70- & $\mathrm{C} 70$ & $\mathrm{C} 70$ & C70-G15- & & & & & & \\
\hline & C100 & CS60 & $\mathrm{S} 30$ & G30 & CS30 & G15-S15 & CS30-AL & S15-AL & & A & B & $\mathrm{C}$ & $\mathrm{D}$ & $\mathrm{E}$ \\
\hline Total VFA, $\mathrm{mmol} / \mathrm{L}$ & 131 & 108 & 115 & 134 & 143 & 130 & 132 & 150 & 12.2 & NS & NS & NS & $\dagger$ & NS \\
\hline Acetate, $\%$ & 51.7 & 54.5 & $62.1^{\mathrm{a}}$ & $56.1^{\mathrm{b}}$ & $52.8^{\mathrm{b}}$ & 60.2 & 55.4 & 57.0 & 1.4 & $* * *$ & $* * *$ & NS & NS & NS \\
\hline Propionate, \% & 28.8 & 21.6 & 24.0 & 26.1 & 27.3 & 22.0 & 26.2 & 24.7 & 1.4 & $* * *$ & NS & $\dagger$ & ** & NS \\
\hline Butyrate, \% & 13.6 & 16.6 & $9.9^{\mathrm{b}}$ & $13.1^{\mathrm{ab}}$ & $14.1^{\mathrm{a}}$ & 12.0 & 13.2 & 14.2 & 1.3 & NS & $*$ & NS & NS & NS \\
\hline Valerate, $\%$ & 3.8 & 4.5 & $2.4^{\mathrm{b}}$ & $3.8^{\mathrm{a}}$ & $4.3^{\mathrm{a}}$ & 2.9 & 4.0 & 3.2 & 0.3 & NS & $* * *$ & NS & NS & NS \\
\hline Lactate, $\mathrm{mmol}$ & 9.4 & 4.7 & 8.2 & 10.9 & 4.6 & 11.8 & 2.0 & 4.0 & 2.3 & NS & $\dagger$ & NS & NS & * \\
\hline Ammonia, mmol/L & 25.8 & 10.4 & 12.4 & 16.2 & 13.7 & 21.0 & 8.2 & 12.7 & 2.5 & **** & NS & $*$ & NS & ** \\
\hline Reducing sugars, $\mathrm{g} / \mathrm{kg}$ of DM & & & & & & & & & & & & & & \\
\hline of ru & 62.0 & 67.5 & $63.8^{\mathrm{ab}}$ & $75.1^{\mathrm{a}}$ & $47.7^{\mathrm{b}}$ & 58.7 & 52.8 & 51.6 & 8.6 & NS & $*$ & NS & NS & NS \\
\hline Co recovery, $\%$ & 21.8 & 26.1 & 28.9 & 30.1 & 22.9 & 20.5 & 31.3 & 34.9 & 7.2 & NS & NS & $\dagger$ & NS & NS \\
\hline
\end{tabular}

${ }^{\mathrm{a}, \mathrm{b}}$ Means in the same row, within columns C70-S30, C70-G30, and C70-CS30 with different superscript differ significantly $(P<0.05)$.

${ }^{1}$ Treatments: $\mathrm{C} 100=$ concentrate only; C40-CS60 = concentrate $(40 \%)$ with corn silage $(60 \%)$; C70-S30 = concentrate $(70 \%)$ with straw $(30 \%)$; C70-G30 = concentrate $(70 \%)$ with dried grass (30\%); C70-CS30 = concentrate $(70 \%)$ with corn silage $(30 \%)$; C70-G15-S15 = concentrate (70\%) with dried grass (15\%) and straw (15\%); C70-CS30-AL = concentrate (70\%) with corn silage (30\%) fed ad libitum; and C70-G15-S15$\mathrm{AL}=$ concentrate $(70 \%)$ with dried grass $(15 \%)$ and straw $(15 \%)$ fed ad libitum.

${ }^{2}$ Contrasts: $\mathrm{A}=\mathrm{C} 100$ vs. (all diets with additional roughage except the 2 ad libitum diets); B = C70-S30 vs. C70-G30 vs. C70-CS30 (mutually); $\mathrm{C}=\mathrm{C} 70-\mathrm{G} 15-\mathrm{S} 15$ vs. (C70-S30 and C70-G30); D = C70-CS30 vs.C40-CS60); E = (C70-G15-S15 and C70-CS30) vs. (ad libitum diets).

$\dagger P<0.10 ; * P \leq 0.05$; ** $P \leq 0.01 ; * * * P<0.001$.

Ruminal concentrations of ammonia ranged from 8.2 to $25.8 \mathrm{mmol} / \mathrm{L}$ and were lower in ad libitum-fed calves (contrast E; $P<0.01$ ) and higher in calves fed concentrates only (contrast A; $P<0.001$ ). Finally, calves fed a mixture of grass and straw as source of roughage had higher concentrations of ammonia than calves fed either grass or straw as a roughage source (contrast C; $P<0.05$ ).

The concentration of RS varied between 47.7 and 75.1 $\mathrm{g} / \mathrm{kg}$ of DM of whole rumen content. Calves fed the C70CS30 diet had a lower RS concentration $(47.7 \mathrm{~g} / \mathrm{kg}$ of $\mathrm{DM})$ than calves fed the C70-G30 diet (75.1 g/ $/ \mathrm{kg}$ of DM; contrast B; $P<0.05$ ). Ad libitum feeding did not have an effect on the rumen RS concentration (contrast $\mathrm{E}$, $P>0.05$ ).

The recovery of Co ranged from 21.8 to $34.9 \%$ and was highly variable among calves within treatments. Calves fed the C70-G15-S15 diet tended to have lower Co recoveries than calves fed either C70-G30 or C70S30 diets $(P<0.1$; contrast $\mathrm{C})$.

Results from the analysis of covariance showed that variation in DMI (average during the last week before slaughter) significantly explained variation in total VFA, the molar proportion of butyrate, and the concentration of ammonia (estimates of regression coefficients \pm SE for DMI: $77.1 \pm 22.4,0.53 \pm 0.22$, and $-11.5 \pm 4.7$, respectively; $P<0.05$ ). Because DMI in calves fed ad libitum was much higher than in calves fed restricted diets (Table 3), but dietary treatments did not significantly affect total VFA concentrations (Table 4), the contrast between restricted and ad libitum diets (contrast E) in total VFA concentrations became significant $(P=0.01)$ after analysis of covariance. Significant differences in the molar proportion of butyrate among dietary treatments C70-S30, C70-G30, and C70-CS30 (contrast B) consistently coincided with differences in DMI (Tables 3 and 4). Thus, following analysis of covariance, contrast $\mathrm{B}$ in the molar proportion of butyrate was no longer significant $(P>0.05)$. Likewise, the significant contrast between restricted and ad libitum diets in the concentration of ammonia (Table 4, contrast E) became nonsignificant after analysis of covariance because of accompanying differences in DMI (Table 3).

Effects of time between last feeding and slaughter on rumen $\mathrm{pH}$, total VFA and lactate concentrations, and Co recovery are shown in Table 5 . Rumen $\mathrm{pH}$ was not significantly influenced by the time of slaughter $(P>$ $0.05)$. However, the total VFA concentrations in rumen fluid increased from $108.3 \mathrm{mmol} / \mathrm{L}$ at $1.5 \mathrm{~h}$ postfeeding to $143.8 \mathrm{mmol} / \mathrm{L}$ at $3.5 \mathrm{~h}$ postfeeding and decreased to $134.6 \mathrm{mmol} / \mathrm{L}$ by $4.5 \mathrm{~h}$ postfeeding $(P<0.05)$. Lactate 
Table 5. Effect of time of sampling after feeding on rumen $\mathrm{pH}$, rumen VFA, rumen lactate and Co recovery

\begin{tabular}{lrrrrrr}
\hline & \multicolumn{5}{c}{ Time after feeding $(\mathrm{h})$} & \\
\cline { 2 - 5 } Variable & 1.5 & 2.5 & 3.5 & 4.5 & SEM & $P$-value \\
\hline $\mathrm{pH}$ & 5.20 & 5.22 & 5.15 & 5.28 & 0.05 & $\mathrm{NS}$ \\
Total VFA, mmol/L & $108.3^{\mathrm{b}}$ & $134.8^{\mathrm{a}}$ & $143.8^{\mathrm{a}}$ & $134.6^{\mathrm{a}}$ & 8.0 & $* *$ \\
Lactate, $\mathrm{mmol} / \mathrm{L}$ & $12.4^{\mathrm{a}}$ & $7.8^{\mathrm{b}}$ & $5.4^{\mathrm{bc}}$ & $2.3^{\mathrm{c}}$ & 1.5 & $* * *$ \\
Co recovery, \% & $48.0^{\mathrm{a}}$ & $26.8^{\mathrm{b}}$ & $18.3^{\mathrm{bc}}$ & $13.2^{\mathrm{c}}$ & 3.2 & $* * *$ \\
\hline
\end{tabular}

${ }^{\mathrm{a}-\mathrm{c}}$ Means in the same row with different superscript differ significantly $(P<0.05)$.

$* * P \leq 0.01 ; * * * P<0.001$.

concentration and Co recovery declined with time postfeeding $(P<0.001)$.

\section{Macroscopic and Microscopic Evaluation of the Rumen Wall}

Results from the macroscopic evaluation of the rumen mucosa are shown in Table 6. The incidence of plaque formation was affected by dietary treatments and varied between 0 and $100 \%$. The rumen mucosa of calves fed the C100, C70-CS30, and C40-CS60 diets showed higher incidence of plaque formation (63 to 100\%) than those fed the C70-S30, C70-G30, or ad libitum diets (0 to $13 \% ; P<0.05)$. Although in some dietary treatments the incidence of calves with poor developed mucosa was $0 \%$, no significant differences $(P>0.05)$ were observed.

Empty rumen weights and the morphometric parameters of the rumen wall are presented in Table 7 . The empty rumen weights of the calves varied between 953 and 1,448 g. Calves in the ad libitum-fed groups had heavier empty rumen weight $(P<0.001$; contrast $\mathrm{E})$. Likewise, among restricted-fed treatments, calves on the all-concentrate diet showed the highest averaged empty rumen weight $(P<0.001$; contrast $\mathrm{A})$.

In the dorsal rumen location, calves fed dried grass as additional source of roughage showed a higher RMSL than those fed with either straw or corn silage $(P<$ 0.05 ; contrast B). Furthermore, ad libitum-fed calves tended to have $(P<0.1)$ an increased MCT compared with restricted-fed calves (contrast E; $P<0.1$ ). Finally, increasing the corn silage to concentrate ratio tended to increase MST (contrast $\mathrm{D} ; P<0.1$ ). In the ventral location of the rumen, except for a decrease in the MST of the rumen wall in calves fed all concentrate diet (contrast A, $P<0.05$ ), no other treatment effects were observed.

The analysis of covariance of rumen weight and the rumen wall morphometric parameters revealed that variation in empty rumen weight was significantly explained by variation in DMI (average during the entire experimental period; estimate of regression coefficient \pm SE for DMI: $651 \pm 145, P<0.001)$. Variation in DMI tended to explain variation in the RMSL and MCT in the ventral rumen (estimates of regression coefficients \pm SE for DMI: $2.91 \pm 1.52$, and $695 \pm 370$, respectively; $P<0.07)$.

\section{Enzyme Activity in Whole Rumen Contents}

The effects of experimental treatments on PDE activities extracted from the whole rumen contents are presented in Table 8 . With soybean hulls as substrate, PDE activities varied between 1.8 and $4.1 \mathrm{mmol} / \mathrm{min}$ per g of DM. Calves fed C70-G30 showed higher PDE activities than those fed C70-S30 or C70-CS30 (contrast B; $P<0.001)$. Furthermore, ad libitum-fed calves had

Table 6. Effect of dietary treatments on the incidence of poorly developed rumen mucosa and the incidence of plaque formation (macroscopic)

\begin{tabular}{|c|c|c|c|c|c|c|c|c|}
\hline \multirow[b]{2}{*}{ Variable } & \multicolumn{8}{|c|}{ Dietary treatment $^{1}$} \\
\hline & C100 & $\begin{array}{l}\text { C40- } \\
\text { CS60 }\end{array}$ & $\begin{array}{l}\text { C70- } \\
\text { S30 }\end{array}$ & $\begin{array}{l}\text { C70- } \\
\text { G30 }\end{array}$ & $\begin{array}{l}\text { C70- } \\
\text { CS30 }\end{array}$ & $\begin{array}{c}\text { C70- } \\
\text { G15-S15 }\end{array}$ & $\begin{array}{c}\text { C70- } \\
\text { CS30-AL }\end{array}$ & $\begin{array}{l}\text { C70-G15- } \\
\text { S15-AL }\end{array}$ \\
\hline Plaque, $\%$ of calves & $100^{\mathrm{a}}$ & $63^{\mathrm{a}}$ & $13^{\mathrm{b}}$ & $13^{\mathrm{b}}$ & $88^{\mathrm{a}}$ & $50^{\mathrm{ab}}$ & $0^{\mathrm{b}}$ & $0^{\mathrm{b}}$ \\
\hline Poor development of mucosa, $\%$ of calves & 38 & 25 & 25 & 0 & 0 & 0 & 0 & 0 \\
\hline
\end{tabular}


Table 7. Effect of dietary treatments on rumen weight and morphometric variables of rumen wall

\begin{tabular}{|c|c|c|c|c|c|c|c|c|c|c|c|c|c|c|}
\hline \multirow[b]{3}{*}{ Variable } & \multicolumn{8}{|c|}{ Dietary treatment ${ }^{1}$} & \multirow[b]{3}{*}{ SEM } & \multirow{2}{*}{\multicolumn{5}{|c|}{ Contrast $^{2}$}} \\
\hline & \multirow[b]{2}{*}{ C100 } & \multirow{2}{*}{$\begin{array}{l}\text { C40- } \\
\text { CS60 }\end{array}$} & \multirow{2}{*}{$\begin{array}{l}\text { C70- } \\
\text { S30 }\end{array}$} & \multirow{2}{*}{$\begin{array}{l}\text { C70- } \\
\text { G30 }\end{array}$} & \multirow{2}{*}{$\begin{array}{l}\text { C70- } \\
\text { CS30 }\end{array}$} & \multirow{2}{*}{$\begin{array}{c}\text { C70- } \\
\text { G15-S15 }\end{array}$} & \multirow{2}{*}{$\begin{array}{c}\text { C70- } \\
\text { CS30-AL }\end{array}$} & \multirow{2}{*}{$\begin{array}{c}\text { C70-G15- } \\
\text { S15-AL }\end{array}$} & & & & & & \\
\hline & & & & & & & & & & A & B & $\mathrm{C}$ & $\mathrm{D}$ & $\mathrm{E}$ \\
\hline $\begin{array}{l}\text { Ratio of mucosa length } \\
\text { to serosa length }\end{array}$ & 5.0 & 4.2 & $4.0^{\mathrm{b}}$ & $5.0^{\mathrm{a}}$ & $4.0^{\mathrm{b}}$ & 3.9 & 4.7 & 4.3 & 0.4 & NS & $*$ & NS & NS & NS \\
\hline Mucosa thickness, $\mu \mathrm{m}$ & 702 & 681 & 506 & 602 & 541 & 415 & 787 & 516 & 88.1 & NS & NS & NS & NS & $\dagger$ \\
\hline $\begin{array}{l}\text { Ratio of mucosa length } \\
\text { to serosa length }\end{array}$ & 4.3 & 4.0 & 4.2 & 4.2 & 4.5 & 4.0 & 5.3 & 4.6 & 0.5 & NS & NS & NS & NS & NS \\
\hline Muco & 595 & 572 & 593 & 348 & 556 & 586 & 695 & 628 & 118 & NS & NS & NS & NS & NS \\
\hline Muscle thickness, $\mu \mathrm{m}$ & 815 & 1,204 & 1,198 & 1,051 & 1,035 & 1,000 & 867 & 1,027 & 123 & * & NS & NS & NS & NS \\
\hline
\end{tabular}

${ }^{\mathrm{a}, \mathrm{b}}$ Means in the same row, within columns C70-S30, C70-G30, and C70-CS30 with different superscripts differ significantly $(P<0$. 05).

${ }^{1}$ Treatments: $\mathrm{C} 100=$ concentrate only; C40-CS60 = concentrate $(40 \%)$ with corn silage $(60 \%)$; C70-S30 = concentrate $(70 \%)$ with straw (30\%); C70-G30 = concentrate (70\%) with dried grass (30\%); C70-CS30 = concentrate (70\%) with corn silage (30\%); C70-G15-S15 = concentrate $(70 \%)$ with dried grass (15\%) and straw (15\%); C70-CS30-AL = concentrate (70\%) with corn silage (30\%) fed ad libitum; and C70-G15-S15$\mathrm{AL}=$ concentrate $(70 \%)$ with dried grass $(15 \%)$ and straw $(15 \%)$ fed ad libitum.

${ }^{2}$ Contrasts: $\mathrm{A}=\mathrm{C} 100$ vs. (all diets with additional roughage, except the 2 ad libitum diets); B = C70-S30 vs. C70-G30 vs. C70-CS30 (mutually); C = C70-G15-S15 vs. (C70-S30 and C70-G30); D = C70-CS30 vs. C40-CS60); E = (C70-G15-S15 and C70-CS30) vs. (ad libitum diets).

$\dagger P<0.10 ; * P \leq 0.05 ; * * * P<0.001$.

decreased PDE activities when compared with restricted-fed calves (contrast E; $P<0.001$ ). With sugar beet pulp as substrate, the PDE activities varied between 3.1 and $6.5 \mathrm{mmol} / \mathrm{min}$ per g of DM. Among restricted-fed treatments, the calves fed concentrate showed higher PDE activities than those fed additional roughage (contrast A; $P<0.001$ ). With native cornstarch as substrate, the PDE activities varied between 2.2 and $9.4 \mathrm{mmol} / \mathrm{min}$ per $\mathrm{g}$ of DM. Calves fed C70-S30 showed lower PDE activities than those fed C70-CS30 or C70-G30, respectively (contrast B; $P<0.001$ ). Ad libitum-fed calves had lower PDE activities than those fed restrictedly (contrast E; $P<0.001$ ). Finally, PDE activities in calves fed a combination of straw and grass
(C70-G15-S15) were lower than in calves fed either straw or dried grass (contrast C; $P<0.001$ ). With straw as substrate, the PDE activities varied between 0.4 and $0.7 \mathrm{mmol} / \mathrm{min}$ per $\mathrm{g}$ of DM. Ad libitum-fed calves had lower PDE activities than restricted-fed calves (contrast E; $P<0.001)$. Moreover, calves fed concentrates only tended to have lower PDE activity (contrast A; $P$ $<0.1)$.

\section{DISCUSSION}

\section{Feed Intake and BW Gain}

In the present experiment, DMI from concentrate and roughage was restricted to $750 \mathrm{~g} / \mathrm{d}$ in all except the ad

Table 8. Effects of dietary treatments on enzyme activity of whole rumen contents (mmol of RS/min per g of DM)

\begin{tabular}{|c|c|c|c|c|c|c|c|c|c|c|c|c|c|c|}
\hline \multirow[b]{3}{*}{ Substrate } & \multicolumn{8}{|c|}{ Dietary treatment ${ }^{1}$} & \multirow[b]{3}{*}{ SEM } & \multirow{2}{*}{\multicolumn{5}{|c|}{ Contrast $^{2}$}} \\
\hline & & $\mathrm{C} 40-$ & $\mathrm{C} 70-$ & $\mathrm{C} 70-$ & C70- & $\mathrm{C} 70-$ & C70- & $\overline{\text { C70-G15- }}$ & & & & & & \\
\hline & C100 & CS60 & S30 & G30 & CS30 & G15-S15 & CS30-AL & S15-AL & & $\mathrm{A}$ & $\mathrm{B}$ & $\mathrm{C}$ & $\mathrm{D}$ & $\mathrm{E}$ \\
\hline Sugar beet pulp & 6.5 & 3.4 & 3.7 & 3.5 & 3.1 & 3.3 & 3.8 & 3.9 & 0.3 & $* * *$ & NS & NS & NS & NS \\
\hline Native corn starch & 6.4 & 9.4 & $3.2^{\mathrm{b}}$ & $7.7^{\mathrm{a}}$ & $8.4^{\mathrm{a}}$ & 2.8 & 2.5 & 2.2 & 0.5 & NS & $* * *$ & $* * *$ & NS & $* * *$ \\
\hline Straw & 0.4 & 0.7 & 0.5 & 0.7 & 0.7 & 0.6 & 0.4 & 0.5 & 0.1 & $\dagger$ & NS & NS & NS & * \\
\hline
\end{tabular}

${ }^{\mathrm{a}, \mathrm{b}}$ Means in the same row, within columns C70-S30, C70-G30, and C70-CS30 with different superscripts differ significantly $(P<0.05)$.

${ }^{1}$ Treatments: $\mathrm{C} 100=$ concentrate only; C40-CS60 = concentrate $(40 \%)$ with corn silage $(60 \%)$; C70-S30 = concentrate $(70 \%)$ with straw $(30 \%)$; C70-G30 = concentrate $(70 \%)$ with dried grass (30\%); C70-CS30 = concentrate $(70 \%)$ with corn silage (30\%); C70-G15-S15 = concentrate $(70 \%)$ with dried grass $(15 \%)$ and straw (15\%); C70-CS30-AL = concentrate (70\%) with corn silage (30\%) fed ad libitum; and C70-G15-S15$\mathrm{AL}=$ concentrate $(70 \%)$ with dried grass $(15 \%)$ and straw $(15 \%)$ fed ad libitum.

${ }^{2}$ Contrasts: $\mathrm{A}=\mathrm{C} 100$ vs. (all diets with additional roughage, except the 2 ad libitum diets); B = C70-S30 vs. C70-G30 vs. C70-CS30 (mutually); $\mathrm{C}=\mathrm{C} 70-\mathrm{G} 15-\mathrm{S} 15$ vs. (C70-S30 and C70-G30); D = C70-CS30 vs. C40-CS60); E = (C70-G15-S15 and C70-CS30) vs. (ad libitum diets).

$\dagger P<0.10 ; * P \leq 0.05 ; * * * P<0.001$. 
libitum-fed treatments. Treatment effects on DMI of roughage and concentrates in this experiment were comparable with effects on feed intake found previously in the literature (Mertens, 1997; compare contrast B, Table 3) where an increased fiber content negatively affected DMI (Mertens, 1997; compare contrast B, Table 3). Substituting a part of the concentrate with roughage, however, did not affect DMI and ADG (contrast A).

The lower intake of milk replacer in the ad libitumfed calves does not allow a direct comparison of calf performance across treatments. Therefore, growth rates on both intake levels of milk replacer were simulated using the growth model of Gerrits et al. (1997). Additional growth (AG) from roughage and concentrate was calculated by the difference between the observed $\mathrm{ADG}$ and the simulated $\mathrm{ADG}$ on milk replacer only, and expressed per unit of DMI from concentrate and roughage. Additional growth in the various treatments ranged from 0.49 to 0.55 and from 0.46 to $0.50 \mathrm{~kg} / \mathrm{kg}$ of feed for restricted- and ad libitum-fed calves, respectively. For restricted-fed calves, AG for calves fed the C-100 diet was higher $(0.55 \mathrm{~kg} / \mathrm{kg})$ than for calves fed C70-S30 $(0.49 \mathrm{~kg} / \mathrm{kg})$. This may be related to the increased yield of absorbed nutrients of concentrates when compared with straw. Moreover, among ad libitum-fed groups a lower AG was obtained in calves fed the C70-G15-S15-AL diet than in those fed the C70CS30-AL diet. Finally, restricted-fed calves showed increased average AG $(0.52 \mathrm{~kg} / \mathrm{kg})$ when compared with ad libitum-fed calves $(0.48 \mathrm{~kg} / \mathrm{kg})$.

In the present experiment, the observed AG in the restricted treatments was not within the AG range observed in a previous experiment (Suárez et al., 2006a). Moreover, the AG on the all concentrate diet was slightly lower than the AG obtained in a previous experiment where a similar diet was fed to calves until 8 or 12 wk of age ( 0.86 and $0.61 \mathrm{~kg} / \mathrm{kg}$, respectively; Suárez et al., 2006a).

\section{Ruminal Fermentation Parameters}

In the present experiment an unexpectedly small range of low rumen $\mathrm{pH}$ was observed (5.1 to 5.3) and roughage did not significantly increase rumen $\mathrm{pH}$. The rumen $\mathrm{pH}$ of the calves fed the concentrate-only diet is in line with the value of 5.2 reported previously in calves aged 8 and 12 wk fed a similar diet (Suárez et al., 2006a). In rearing calves, maximum VFA concentrations have been reported 3 to $4 \mathrm{~h}$ postfeeding $(\approx 100$ to $110 \mathrm{mmol} / \mathrm{L}$; Stobo et al., 1966). In line with these findings, maximum VFA concentrations in the present experiment were observed $3.5 \mathrm{~h}$ after feeding. In this experiment, the total VFA concentrations were close to those observed in adult ruminants (120 to $160 \mathrm{mmol} /$ L; Bergman, 1990) and to those observed in roughagesupplemented rearing calves $(\approx 120 \mathrm{mmol} / \mathrm{L}$; VázquezAnon et al., 1993; $\approx 150 \mathrm{mmol} / \mathrm{L}$; Zitnan et al., 1998). Total VFA concentrations of calves fed C-100 observed in this study were higher than those previously recorded in calves fed a similar diet and slaughtered at a similar age (Suárez et al. 2006a), mostly likely reflecting differences in time of sampling postfeeding (1 to $3 \mathrm{~h}$ vs. 1.5 to $4.5 \mathrm{~h}$, respectively). Ruminant diets based on roughage, especially those rich in structural carbohydrates, are known to produce high molar proportions of acetate. Furthermore, as the roughage to concentrate ratio decreases, the acetate to propionate ratio also decreases (Bannink et al., 2006). In line with these observations, the molar proportion of acetate in the current trial increased when straw was present in the diet (see Table 4, contrast B). Also, molar proportions of acetate and propionate were lowest and highest, respectively, in calves fed the all concentrate diet (contrast A), in agreement with observations in rearing calves (Bull et al., 1965; Stobo et al., 1966; Anderson et al., 1982; Zitnan et al., 1998). The effect of diet on the molar proportion of butyrate seemed to be mediated by DMI, because the contrast among C70-S30, C70G30, and C70-CS30 (contrast B) was no longer significant after analysis of covariance with the average DMI during the last week before slaughter acting as a covariable.

Lactate concentration in rumen fluid was reduced in the ad libitum-fed groups ( $\approx 3.1$ vs. $\approx 8.3 \mathrm{mmol} / \mathrm{L})$. In addition, lactate concentrations in the restricted-fed groups were close to concentrations reported in adult ruminants facing subclinical acidosis $(\approx 10 \mathrm{mmol} / \mathrm{L}$; Hristov et al., 2001). The lower concentrations in the ad libitum-fed groups may reflect an improved capability of rumen microorganisms to utilize lactate (Counotte et al., 1981; Williams and Martin, 1990; Van Soest, 1994). The rapid decline in lactate concentrations after $1.5 \mathrm{~h}$ after feeding is in line with observations reported in dairy cattle (Chamberlain et al., 1983; Counotte et al., 1983). Finally, the lactate concentration of the control group (C-100) observed in this study $(9.4 \mathrm{mmol} / \mathrm{L})$ was higher than that previously recorded in calves fed a similar diet ( $5 \mathrm{mmol} / \mathrm{L}$; Suárez et al., 2006a).

The ammonia concentrations reported in this experiment are within the range reported by Zitnan et al. (1998) of 6 to $21 \mathrm{mmol} / \mathrm{L}$ in rearing calves fed concentrate and supplemented with roughage (alfalfa). Ammonia concentrations were clearly associated with DMI; correcting for differences in DMI removed significance of the contrast in ammonia between restricted and ad libitum diets. The reduced ammonia concentrations in calves fed ad libitum may indicate an improved utiliza- 
tion (higher microbial efficiency) by the rumen microorganisms related to increased fractional passage rates that usually occur upon higher DMI levels (Dijkstra et al., 2002), or increased absorption across a more mature rumen wall. The implication of higher microbial efficiency is supported by a decrease in the proportion of branched-chain VFA observed in the ad libitum-fed groups. Branched-chain VFA are mainly endproducts of protein fermentation and are, along with ammonia, often used as quick indicators of protein fermentation in the rumen (Yang, 2002).

The etiology of ruminal drinking (ruminal drinkers refers to calves that develop chronic indigestion because milk is deposited into the rumen as a result of failure of the reticular groove reflex during drinking) has been well described (Pochòn, 2002). The pathology with the clinical symptoms was experimentally reproduced by Van Weeren-Keverling Buisman et al. (1990a,b), and the metabolic and endocrine profiles were characterized by Herrli-Gygi et al. (2006). Quantitative information on ruminal drinking, however, is scarce and absent in calves fed concentrates or roughage in addition to milk replacer. Small amounts of milk leakage have been observed in normal veal calves $(\approx 3 \%)$, but quite considerable amounts have been reported in veal calves considered clinically sick (up to 50\%; Dos Santos et al., 1986). In the present study, although the presence of milk replacer in rumen was considerable $(\approx 25 \%)$, the concentrations of lactate were lower than results reported by Gentile et al. (2004) in clinically sick animals (15 to 30 $\mathrm{mmol} / \mathrm{L}$ ). Moreover, despite the on-average high recovery of Co in the rumen, none of the calves showed signs of illness, such as reduced appetite or bloat, which indicates that in veal calves fed additional solid feeds (either concentrate or concentrate with roughage) a substantial amount of milk can flow into the rumen without inducing symptoms of the syndrome. The marker technique used does not allow discrimination between the functioning of the esophageal groove reflex and potential reflux of milk replacer from the abomasum, and the technique may suffer from some limitations. Potential influences of transport and slaughter procedures on Co recovery cannot be excluded, although extreme caution was taken to avoid any such bias. The fractional passage rate of rumen liquid was estimated at $46 \% / \mathrm{h}$ (see Materials and Methods), which is extremely high when compared with adult cows $(\approx 15 \% / \mathrm{h}$; Offer and Dixon, 2000). Applying this fractional passage rate to estimate the Co pool size at time zero indicates that all milk replacer entered the rumen, suggesting either methodological problems or that variable fractional passage rates apply. Nonetheless, because there is currently no ideal technique available to quantify ruminal drinking and estimate rumen passage rate in veal calves, the high recovery of Co in the rumen illustrates a potentially large problem, worthy of further investigation.

\section{Macroscopic and Microscopic Evaluation of the Rumen Wall}

Previously, Suárez et al. (2006b) observed, in concentrate-only supplemented calves, a high incidence of plaque formation (see Figure 1) and poor rumen development when judged macroscopically. The occurrence of plaque has been related to the absence of coarse material in the rumen (Nocek et al., 1984). Similar observations were described by Di Giancamillo et al. (2003) in veal calves fed either pelleted or extruded diets. In the present trial, the macroscopic evaluation of the rumen clearly showed the beneficial effects of roughage (except corn silage treatments fed restrictedly) to reduce incidence of plaque and of poorly developed mucosa (see Table 6). The increased empty rumen weight found in calves fed concentrate only may have been influenced by plaque formation. The ad libitum treatments resulted in significantly higher empty rumen weights related to the higher intake, but no plaque was observed in these calves.

Harrison et al. (1960) already suggested that adequate physical stimulation ("roughage scratch factor") is required to maintain a healthy rumen mucosa and to stimulate rumen motility and consequently the proper development of the muscular wall. Despite the effect of roughage intake on the macroscopic evaluation of rumen mucosa, the addition of roughage hardly affected the microscopic morphology of the rumen wall. Roughage addition did significantly increase MST in the ventral rumen indicating enhanced physical stimulation and rumen motility.

\section{Enzyme Activity and Soluble Sugars in Rumen Contents}

Quantification of the activity of various enzyme systems in whole rumen contents is a way to evaluate the capability of the ruminal microflora to degrade the dietary substrates (Silva et al., 1987; Suárez et al., 2006a). Treatment effects on PDE (a consortium of enzyme activities incubated with various natural substrates) observed in this experiment generally indicated an adaptation of the rumen microorganism to the diets, similar to effects observed by Suárez et al. (2006a). In the present experiment, the activities of most PDE (except when using sugar beet pulp as a substrate, Table 8) were reduced in the ad libitum-fed groups, indicating a reduced fractional substrate hydrolysis rate at high intake levels. The increased enzyme activity in restricted fed calves may be the result of different pat- 

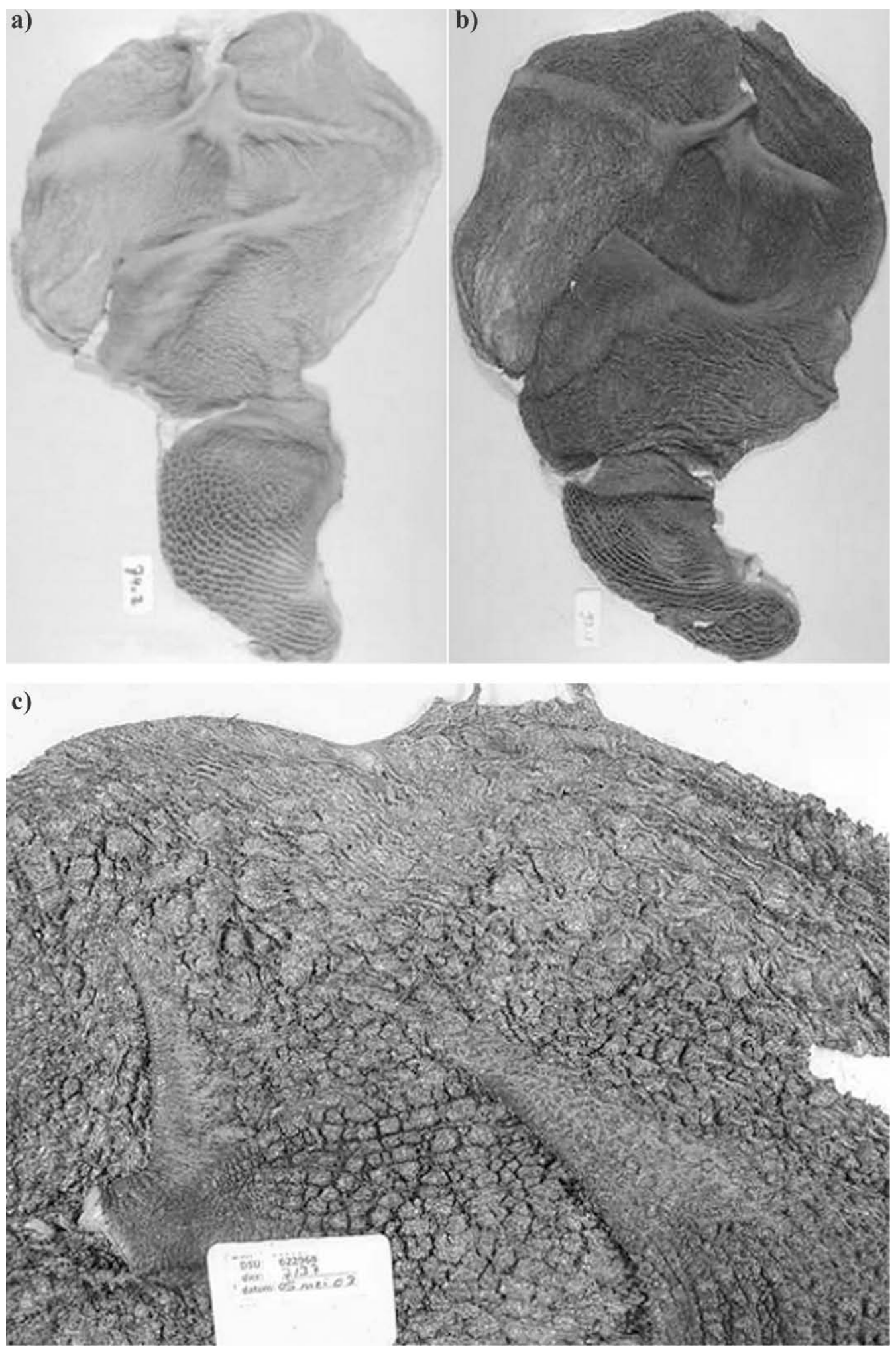

Figure 1. a) Photograph showing a poor development of the rumen mucosa, with little papillae and a lack of healthy dark coloration associated with microbial fermentation in the rumen; b) photograph showing an excellent mucosa development, with a healthy dark coloration associated with proper feeding of veal calves (up to $10 \mathrm{wk}$ of age). The dark brown color is due to a microbial fermentation and increased mucosa development; c) photograph showing the plaque formations in the rumen mucosa (plaque = rumen mucosa containing focal or multifocal patches with coalescing and adhering papillae covered by a sticky mass of feed, hair, and cell debris). 
terns of feed intake and consequently of microbial activity. Ad libitum-fed calves consumed the concentrate and roughage portions throughout the day, whereas restricted-fed calves consumed the feed rapidly after supply. Therefore, at time of slaughter, relatively more freshly entered substrate is available for microorganisms in the restricted-fed calves, which may have stimulated enzymatic activity.

In adult ruminants it is assumed that soluble carbohydrates are rapidly taken up by rumen microorganisms. Consequently, concentrations of RS are usually low ( $\approx 0.04$ and $5.55 \mathrm{~g} / \mathrm{kg}$ of DM; Hristov et al., 2000, 2001; Hristov and Ropp, 2003). The results of the present experiment confirm earlier observations of high concentrations of RS in rumen contents (Suárez et al., 2006a). It was suggested that at low $\mathrm{pH}$, high concentrations of RS in rumen contents might result from reduced uptake of RS by the microorganisms to regulate their intracellular $\mathrm{pH}$, while the PDE were still active. The additional supply of roughage in the present experiment did not improve the RS utilization by the rumen microorganisms (see Table 4): concentrations ranged from 47.7 to $75.1 \mathrm{~g}$ of $\mathrm{RS} / \mathrm{kg}$ of DM in the present experiment, and between 45 and $61 \mathrm{~g}$ of $\mathrm{RS} / \mathrm{kg}$ of $\mathrm{DM}$ in the concentrate-fed veal calves in an earlier experiment (Suárez et al., 2006a).

\section{CONCLUSIONS}

The results of the present experiment showed that substitution of part of the concentrate by roughage did not affect DMI and ADG, but among roughage sources, feeding straw reduced DMI and ADG. The addition of roughage did not affect rumen $\mathrm{pH}$, total VFA concentrations, or RS levels, but increased the acetate to propionate ratio. Cobalt recovery, as an indication of milk leakage, was high but not affected by dietary treatments. Ad libitum-fed calves had lower rumen lactate and ammonia levels and a higher empty rumen weight and fresh rumen contents than restricted-fed calves. Results indicated that in veal calves, the addition of roughage to concentrate diets did not affect growth performance and, by decreasing the incidence of plaque formation, positively influenced the macroscopic appearance of the rumen wall. However, morphometric parameters of the rumen wall were hardly influenced by the type and level of roughage.

\section{REFERENCES}

Anderson, M. J., M. Khoyloo, and J. L. Walters. 1982. Effect of feeding whole cottonseed on intake, body weight, and reticulorumen development of young Holstein calves. J. Dairy Sci. 65:764-772.

Bannink, A., J. Kogut, J. Dijkstra, J. France, E. Kebreab, A. M. Van Vuuren, and S. Tamminga. 2006. Estimation of the stoichiometry of volatile fatty acid production in the rumen of lactating cows. J. Theor. Biol. 238:36-51.

Beharka, A. A., T. G. Nagaraja, J. L. Morrill, G. A. Kennedy, and R. D. Klemm. 1998. Effects of form of the diet on anatomical, microbial and fermentative development of the rumen of neonatal calves. J. Dairy Sci. 81:1946-1955.

Bergman, E. N. 1990. Energy contributions of volatile fatty acids from the gastrointestinal tract in various species. Physiol. Rev. 70:567-590.

Blokhuis, H. J., C. G. van Reenen, J. J. Heeres, L. F. M. Heutinck, A. M. van Vuuren, N. Stockhofe, A. E. van de Braak, J. J. de Groot, I. Veissier, B. J. Lensink, L. Florand, M. S. Cockram, G. Cozzi, F. Gottardo, M. Verga, S. Mattiello, E. Canali, S. Raussi, M. Pyykkönen, H. Saloniemi, H. Hepola, and L. Hänninen. 2000. Chain Management of Veal Calf Welfare. Final Report. EU-Project Contract Number FAIR 3 PL96-2049. http://eu.europa.eu/ research/agro/fair/en/nl2049.html Accessed Feb. 20, 2007.

Brunt, K. 1993. Enzymatic determination of starch content in feed and feedstuffs, Memo 93-302 [in Dutch]. Stichting Nederlands Instituut voor Koolhydraat Onderzoek, Groningen, the Netherlands.

Bull, L. S., L. J. Bush, J. D. Friend, B. Harris, Jr., and E. W. Jones. 1965. Incidence of ruminal parakeratosis in calves fed different rations and its relation to volatile fatty acid absorption. J. Dairy Sci. 48:1449-1456.

Chamberlain, D. G., P. C. Thomas, and F. J. Anderson. 1983. Volatile fatty acids proportions and lactic acid metabolism in the rumen in sheep and cattle receiving silage diets. J. Agric. Sci. 101:47-58.

Counotte, G. H. M., A. Lankhorst, and R. A. Prins. 1983. Role of DLlactic acid as an intermediate in rumen metabolism of dairy cows. J. Anim. Sci. 56:1222-1235.

Counotte, G. H. M., R. A. Prins, R. H. A. M. Janssen, and M. J. A. DeBie. 1981. Role of Megasphaera elsdenii in the fermentation of DL-[2-13C] lactate in the rumen of dairy cattle. Appl. Environ. Microbiol. 42:649-655.

Cozzi, G., F. Gottardo, S. Mattiello, E. Canali, E. Scanziani, M. Verga, and I. Andrighetto. 2002. The provision of solid feeds to veal calves: I. Growth performance, forestomach development, and carcass and meat quality. J. Anim. Sci. 80:357-366.

Di Giancamillo, A., G. Bosi, S. Arrighi, G. Savoini, and C. Domeneghini. 2003. The influence of different fibrous supplements in the diet on ruminal histology and histometry in veal calves. Histol. Histopathol. 18:727-733.

Dijkstra, J., J. A. N. Mills, and J. France. 2002. The role of dynamic modelling in understanding the microbial contribution to rumen function. Nutr. Res. Rev. 15:67-90.

Dos Santos, G. T., R. Toullec, R. Roger, and H. de la Grange. 1986. Caracteristiques digestives des veux de boucherie s'adaptant mal en atelier d'engraisement. Reprod. Nutr. Dev. 26:1217.

Flatt, W. P., R. Warner, and J. K. Loosli. 1958. The influence of purified materials on the development of the ruminant stomach. J. Dairy Sci. 41:1593-1600.

Genstat Committee. 2000. Reference Manual. Procedure Library PL12. R.G. Payne and G.M. Arnold, ed. VSN International, Oxford, UK.

Gentile, A., S. Sconza, I. Lorenz, G. Otranto, G. Rademacher, P. Famigli-Bergamini, and W. Klee. 2004. D-Lactic acidosis in calves as a consequence of experimentally induced ruminal acidosis. J. Vet. Med. A Physiol. Pathol. Clin. Med. 51:64-70.

Gerrits, W. J. J., J. Dijkstra, and J. France. 1997. Description of a model integrating protein and energy metabolism in preruminant calves. J. Nutr. 127:1229-1242.

Harrison, H. N., R. G. Warner, E. G. Sander, and J. K. Loosli. 1960. Changes in the tissue and volume of the stomachs of calves following removal of dry feed or consumption of inert bulk. J. Dairy Sci. 43:1301-1312.

Haskins, B. R., M. B. Wise, H. B. Craig, T. N. Blumer, and E. R. Barrack. 1969. Effects of adding low levels of roughage or roughage substitutes to high energy rations of fattening steers. J. Anim. Sci. 29:348-356.

Herrli-Gygi, M., H. M. Hammon, Y. Zbinden, A. Steiner, and J. L. Blum. 2006. Ruminal drinkers: endocrine and metabolic status 
and effects of suckling from a nipple instead of drinking from a bucket. J. Vet. Med. A. Physiol. Pathol. Clin. Med. 53:215-224.

Hinders, R. G., and F. G. Owen. 1965. Relation of ruminal parakeratosis development to volatile fatty acid absorption. J. Dairy Sci. 48:1069-1078

Hodgson, J. 1971. The development of solid food intake in calves. 1. The effect of previous experience of solid food, and the physical form of diets, on the development of food intake after weaning. Anim. Prod. 13:15-24.

Hristov, A. N., M. Ivan, L. M. Rode, and T. A. McAllister. 2001. Fermentation characteristics and ruminal ciliate protozoal populations in cattle fed medium- or high-concentrate barley-based diets. J. Anim. Sci. 79:515-524.

Hristov, A. N., T. A. McAllister, and K.-J. Cheng. 2000. Intraruminal supplementation with increasing levels of exogenous polysaccharide-degrading enzymes: Effects on nutrient digestion in cattle fed a barley grain diet. J. Anim. Sci. 78:477-487.

Hristov, A. N., and J. K. Ropp. 2003. Effect of dietary carbohydrate composition and availability on utilization of ruminal ammonia nitrogen for milk protein synthesis in dairy cows. J. Dairy Sci. $86: 2416-2427$

ISO (International Organization for Standardization). 1978. ISO 5984: Animal Feeding Stuffs. Determination of Crude Ash. ISO, Geneva, Switzerland.

ISO (International Organization for Standardization). 1983. ISO 6496: Animal Feeding Stuffs. Determination of Dry Matter Content, Category B. ISO, Geneva, Switzerland.

ISO (International Organization for Standardization). 1998. 5983 EN: Animal Feeding Stuffs. Determination of Nitrogen Content and Calculation of Crude Protein. ISO, Geneva, Switzerland.

ISO (International Organization for Standardization). 1999. ISONEN 6492 EN: 1999. Animal Feeding Stuffs. Determination of Fat Content, Category B. ISO, Geneva, Switzerland.

McCullagh, P., and J. A. Nelder. 1989. Generalized Linear Models. 2nd ed. Chapman \& Hall, London, UK.

Mertens, D. R. 1997. Creating a system for meeting the fiber requirements of dairy cows. J. Dairy Sci. 80:1463-1481.

Nocek, J. E. 1997. Bovine acidosis: Implications on laminitis. J. Dairy Sci. 80:1005-1028.

Nocek, J. E., C. W. Heald, and C. E. Polan. 1984. Influence of ration physical form and nitrogen availability on ruminal morphology of growing bull calves. J. Dairy Sci. 67:334-343.

Nocek, J. E., and E. M. Kesler. 1980. Growth and rumen characteristics of Holstein steers fed pelleted or conventional diets. J. Dairy Sci. 63:249-254

NRC. 1989. Nutrients Requirements of Dairy Cattle. 6th rev. ed. Natl. Acad. Sci., Washington, DC.

Offer, N. W., and J. Dixon. 2000. Factors affecting outflow rate from the reticulo-rumen. Nutr. Abstr. Rev. (Ser. B) Livest. Feeds Feed. 70:833-844.

Owens, F. N., D. S. Secrist, W. J. Hill, and D. R. Gill. 1998. Acidosis in cattle: A review. J. Anim. Sci. 76:275-286.

Pochòn, D. O. 2002. Surco reticular de los ruminates. Revision bibliogràfica. Rev. Vet. 12/13:2001-2002.

SAS Institute. 2002. SAS User's Guide: Statistics. Release 9.1. SAS Institute Inc., Cary, NC.
Schneider, D. 1976. Determination of ammonia and Kjeldahl nitrogen by indophenol method. Water Res. 10:31-36.

Silva, A. T., R. J. Wallace, and E. R. Ørskov. 1987. Use of particlebound enzyme activity to predict the rate and extent of the fiber degradation in the rumen. Br. J. Nutr. 57:407-415.

Somogyi, M. 1952. Notes on sugars determination. J. Biol. Chem. 195:19-23.

Stobo, I. J. F., J. H. B. Roy, and H. J. Gaston. 1966. Rumen development in the calf. 1 . The effect of diets containing different proportions of concentrates to hay on rumen development. Br. J. Nutr. 20:171-188.

Suárez, B. J., C. G. Van Reenen, G. Beldman, J. van Delen, J. Dijkstra, and W. J. J. Gerrits. 2006a. Effects of supplementing concentrates differing in carbohydrate composition in veal calf diets: I. Animal performance and rumen fermentation characteristics. J. Dairy Sci. 89:4365-4375.

Suárez, B. J., C. G. Van Reenen, W. J. J. Gerrits, N. Stockhofe, A. M. van Vuuren, and J. Dijkstra. 2006b. Effects of supplementing concentrates differing in carbohydrate composition in veal calf diets: II. Rumen development. J. Dairy Sci. 89:4376-4386.

Tamate, H., A. D. McGilliard, N. L. Jacobson, and R. Getty. 1962. Effect of various diets on the anatomical development of the stomach in the calf. J. Dairy Sci. 45:408-420.

Uden, P., P. E. Colucci, and P. J. Van Soest. 1980. Investigation of chromium, cerium and cobalt as markers in digesta rate of passage studies. J. Sci. Food Agric. 31:625-632.

Van Soest, P. J. 1994. Nutritional Ecology of the Ruminant. 2nd ed. Cornell University Press, Ithaca, NY.

Van Soest, P. J., and R. W. McQueen. 1973. The chemistry and estimation of fiber. Proc. Nutr. Soc. 32:123-130.

Van Soest, P. J., J. B. Robertson, and B. A. Lewis. 1991. Methods for dietary fiber, neutral detergent fiber, and non starch polysaccharides in relation to animal nutrition. J. Dairy Sci. 74:35833597.

Van Weeren-Keverling Buisman, A., J. M. V. M. Mouwen, T. Wensing, and H. J. Breukink. 1990a. Intraruminal administration of milk in the calf as a model for ruminal drinking: morphological and enzymatical changes in the jejunal mucosa. Vet. Res. Commun. 14:129-140.

Van Weeren-Keverling Buisman, A., T. Wensing, T. S. G. A. M. Van den Ingh, and H. J. Breukink. 1990b. Intraruminal administration of milk in the calf as a model for ruminal drinking: Clinical aspects and biochemical and morphological changes in the rumen. J. Anim. Physiol. Anim. Nutr. 63:255-266.

Vázquez-Anon, M., A. J. Heinrichs, J. M. Aldrich, and G. A. Varga. 1993. Postweaning age effect on rumen fermentation end products and digesta kinetics in calves weaned at 5 weeks of age. J. Dairy Sci. 76:2742-2748.

Williams, D. K., and S. Martin. 1990. Xylose uptake by the ruminal bacterium Selenomonas ruminantium. Appl. Environ. Microbiol $56: 1683-1688$

Yang, C. M. J. 2002. Response of forage fiber degradation by ruminal microorganisms to branched-chain volatile fatty acids, amino acids, and dipeptides. J. Dairy Sci. 85:1183-1190.

Zitnan, R., J. Voigt, U. Schonhusen, J. Wegner, M. Kokardova, H. Hagemeister, M. Levkut, S. Kuhla, and A. Sommer. 1998. Influence of dietary concentrate to forage ratio on the development of rumen mucosa in calves. Arch. Anim. Nutr. 51:279-291. 